\title{
Implementation of biogas-based energy security program and evaluation of its sustainability in Kediri village, Pringsewu district, Lampung province
}

\author{
Sri Ismiyati Damayanti \\ Chemical Engineering Department, Faculty of Engineering, Lampung University, Indonesia, \\ mya_wid@yahoo.com \\ Simparmin Ginting \\ Chemical Engineering Department, Faculty of Engineering, Lampung University, Indonesia, \\ simparmin@gmail.com
}

See next page for additional authors

Follow this and additional works at: https://scholarhub.ui.ac.id/ajce

Part of the Agricultural and Resource Economics Commons, and the Bioresource and Agricultural Engineering Commons

\section{Recommended Citation}

Damayanti, Sri Ismiyati; Ginting, Simparmin; Nawansih, Otik; and Hudaidah, Siti (2020). Implementation of biogas-based energy security program and evaluation of its sustainability in Kediri village, Pringsewu district, Lampung province. ASEAN Journal of Community Engagement, 4(1).

Available at: https://doi.org/10.7454/ajce.v4i1.1074

Creative Commons License

\section{(c) (i) ()}

This work is licensed under a Creative Commons Attribution-Share Alike 4.0 License.

This Research Article is brought to you for free and open access by the Universitas Indonesia at ASEAN Journal of Community Engagement. It has been accepted for inclusion in ASEAN Journal of Community Engagement. 


\title{
Implementation of biogas-based energy security program and
}

\author{
evaluation of its sustainability in Kediri village, Pringsewu
}

\author{
district, Lampung province
}

\section{Sri Ismiyati Damayantia*, Simparmin Gintinga, Otik Nawansih ${ }^{\mathrm{b}}$, Siti}

\section{Hudaidah $^{\mathrm{c}}$}

\author{
${ }^{a}$ Chemical Engineering Department, Faculty of Engineering, Lampung University, Indonesia \\ bDepartment of Post Harvest Technology, Faculty of Agriculture, Lampung University, Indonesia \\ cDepartment of Fisheries and Marine Science, Faculty of Agriculture, Lampung University, Indonesia
}

Received: March 4th 2020 || Revised: June $26^{\text {th }}, 2020||$ Accepted: July $2^{\text {th }}, 2020$

\begin{abstract}
The Biogas-based energy security program in Kediri Village, Pringsewu District, Lampung Province, aims to provide awareness and knowledge to villagers about the potential of cow dung to be made into biogas and promote awareness of good environment quality. An evaluation of the sustainability of the program in the community was conducted. The methods that were used in this program are (1) socialization to provide awareness of good environment quality and energy security, (2) digester construction and stove and biogas lamp installation, which was carried out by the community together with certified trainers, (3) creation of a master design of the digester layout to ensure the maximum utilization of the digesters, and (4) evaluation to determine opportunities for program sustainability. Results show that the Biogas-based Energy Security Program has succeeded in making the community aware of and accept and apply the technology of processing cow manure into biogas. Biogas has met $100 \%$ of the fuel needs for cooking and electricity of biogas-fed houses. The environment quality has also improved, as shown by clean cages and home environments, and methane emissions have reduced. Over the five-year program, 11 out of 20 planned digesters have been built. The program's future sustainability can be continued by the community, provided that alternative sources of funds that can be pursued by the community are available.
\end{abstract}

Keywords: energy security; biogas; cow dung; environmental quality; sustainability.

\section{Introduction}

Currently, the world community is experiencing an energy crisis caused by the decrease in fossil energy reserves, while the world energy needs continues to increase (Capellan-Perez et al., 2014; Linke et al., 2013; Panwar et al., 2011). Therefore, efforts should be made to increase the use of alternative energy, one of which is renewable energy. Today, renewable energy sources supply $14 \%$ of the total world energy needs, which include biomass, hydropower, geothermal, solar, wind, and marine energy. 
Renewable energy refers to primary, domestic, and clean or inexhaustible energy resources (Kalyani, Dudy \& Pareek, 2015; Panwar et al., 2011; Owusu \& Asumadusarkodie, 2016). According to Panwar et al. (2011), renewable energy sources that meet domestic energy requirements have the potential to provide energy services with zero or almost zero emissions of both air pollutants and greenhouse gases (GHG). The development of renewable energy systems is one solution to current crucial problems, such as increasing the reliability of energy supply and saving on organic fuels, solving local energy, and water supply problems, improving the living standards of the local population, ensuring sustainable development in remote areas, and meeting international agreements. The development and implementation of renewable energy projects in rural areas can create job opportunities to minimize urbanization. Promoting renewable energy in a decentralized way is an option to meet rural energy needs on a small scale that is affordable, environmentally friendly, and sustainable.

The energy crisis is also being felt by the Indonesian people. Therefore, efforts need to be made to realize Indonesia's energy security. Biogas is one of the most promising renewable energy sources (Omer, 2017; Ošlaj \& Muršec, 2010). Biogas can be produced from the decomposition of organic compounds in anaerobic conditions (Khairuddin et al. 2015; Weiland, 2010). Moreover, biogas is environmentally friendly because even though biogas combustion produces GHG, their impact on global warming is much smaller than that of fossil energy (Sharma et al., 2019; Uzodinma et al., 2014; Meyeraurich et al., 2012). At present, the concentration of GHG in the atmosphere is increasing rapidly due to $\mathrm{CO}_{2}$ emissions produced by fossil fuels. GHG emissions must be reduced to less than half the level of global emissions to minimize global warming and the impact of climate change (Weiland, 2010).

Anaerobic digestion is the digestion of organic material with conditions without oxygen. Organic matter is decomposed to produce biogas, the majority of which consists of $\mathrm{CH}_{4}, \mathrm{NH}_{3}, \mathrm{H}_{2} \mathrm{~S}$, and $\mathrm{CO}_{2}$. Anaerobic digestion consists of four stages, namely, digestion of complex organic compounds/insoluble into simple organic compounds (hydrolysis), digestion of simple organic compounds into volatile fatty acids (acidogenesis), formation of acetate (acetogenesis), and formation of methane (methanogenesis) (Nathia-Neves et al., 2018; Bibra et al., 2015). Each stage in anerobic breakdown involves different microorganisms that interact with each other in a system; these 
microorganisms are called syntrophy microorganisms, which utilize products from the previous stage as substrates in the later stages (Deublein \& Steinhauser, 2008). Microorganisms that play a role in the anaerobic breakdown above consist of facultative anaerobic and obligate anaerobic microorganisms. Facultative anaerobic bacteria play a role in the process of hydrolysis and acidogenesis, while obligate microorganisms play a role in the process of acetogenesis and methanogenesis. Obligatory anaerobic microorganisms can grow and carry out their metabolism only in an environment without oxygen. Facultative anaerobic microorganisms have the ability to change their metabolic pathways in an oxygen-containing environment (Nguyen \& Khanal, 2018).

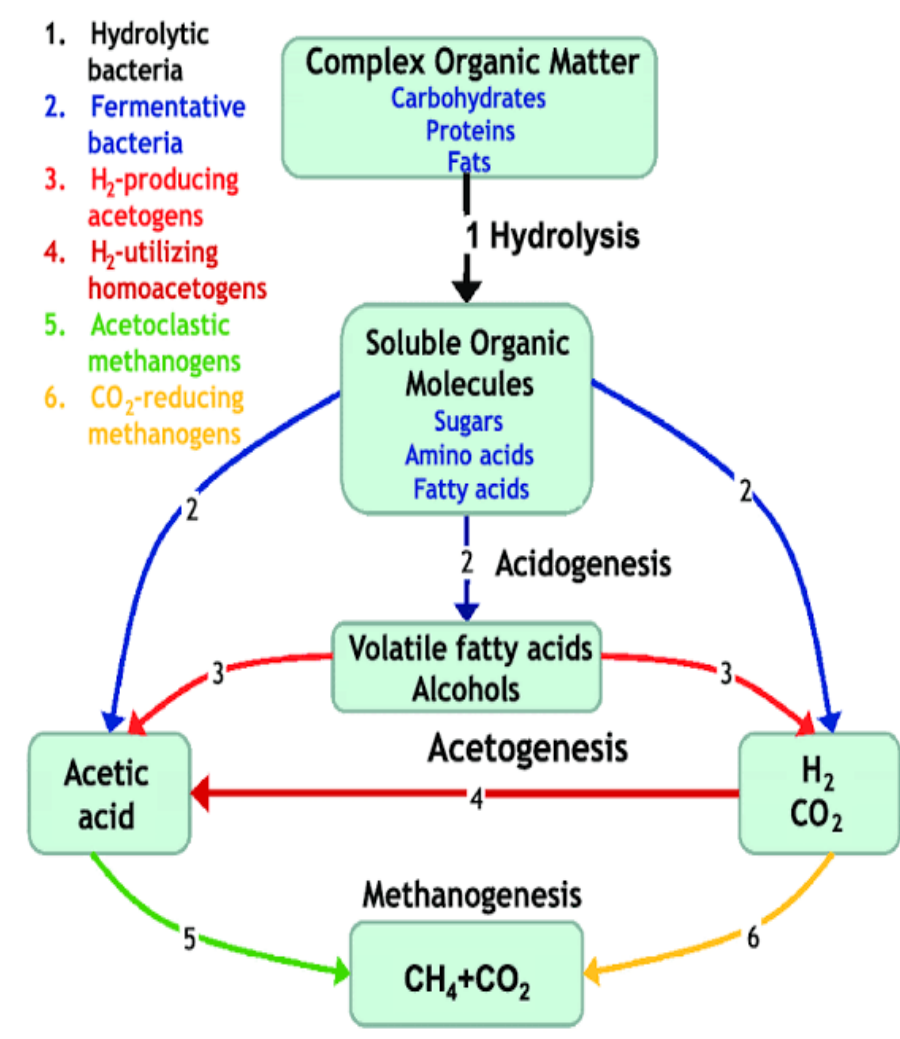

Fg. 1 Anaerobic digestion scheme

Source: Bibra et al., (2015)

The following are the stages of the anerobic decomposition process, such as:

(1) Hydrolysis stage

At this stage, undissolved organic compounds such as cellulose, protein, and fat are remodeled into simple organic compounds (dissolved compounds) by hydrolytic 
bacteria, which are generally facultative anaerobic. Hydrolysis generally has the slowest degradation rate, thus becoming a limiting reaction/stage. Therefore, performing initial treatment aimed at increasing the efficiency of hydrolysis is important to improve the overall efficiency of anaerobic digestion (Lim \& Wang, 2013). One treatment that can be performed during the process is microaeration. Microaeration will increase the rate of hydrolysis, thus ensuring that the hydrolysis process becomes efficient (Yin et al., 2016; Lim \& Wang, 2013). The dissolved organic compound will be processed in the next stage into biogas. During measurement, the amount of organic material that is converted to biogas is expressed by soluble chemical oxygen demand.

(2) Acidogenesis stage

At the acidogenesis stage, simple organic compounds, which are commonly expressed as soluble chemical oxygen demand, are broken down into volatile fatty acid compounds by fermentative bacteria, which are generally facultative anaerobic (Lim et al., 2014). Aside from volatile fatty acids, acetic acid, alcohol, hydrogen, and carbon dioxide $\left(\mathrm{CO}_{2}\right)$ are also formed at this stage (Bibra et al., 2015). The optimal temperature of formation of volatile acids is $35^{\circ} \mathrm{C}$ and pH 5.2-6.5 (Poh \& Chong, 2009).

\section{(3) Acetogenesis stage}

This is the formation stage of acetic acid. The formation of acetate can occur through the degradation of volatile fatty acids from acidogenesis or through the work of hydrogen consuming bacteria $\left(\mathrm{H}_{2}\right)$ (Bibra et al., 2015). From the digestion of volatile fatty acids, $\mathrm{H}_{2}$ and $\mathrm{CO}_{2}$ will also be produced in addition to acetate. The hydrogen and carbon dioxide can be used by hydrogen consuming bacteria to produce acetate (Chojnacka et al., 2015). Acid compounds resulting from the acidogenesis and acetogenesis are generally called volatile fatty acids, which are mostly dominated by acetate, an intermediate product that is used as a methanogen substrate to produce methane (Seadi et al., 2008). 
(4) Methanogenesis stage

The fourth stage is the formation of methane, which takes place under strictly anaerobic conditions (Brioukhanov \& Netrusov, 2007). Methanogenesis can go through three different pathways, namely, acetoclastic methanogenesis, hydrogenothropic methanogenesis, and methylothropic methanogenesis. Acetoclastic methanogenesis produces methane by breaking down acetic acid into $\mathrm{CH}_{4}$. Hydrogenotrophic methanogenesis produces methane by reducing $\mathrm{CO}_{2}$ with $\mathrm{H}_{2}$ or form as an electron donor. Sometimes, alcohol is also used as an electron donor, but this rarely happens. Methylotrophic methanogenesis produces methane by reducing the methyl group from methanol, methylated amine, or methylated sulfide (Chojnacka et al., 2015). The optimum temperature and $\mathrm{pH}$ for archea methanogens are $35^{\circ} \mathrm{C}$ and $\mathrm{pH} 7.5-8.5$ (Poh \& Chong, 2009).

The abundant biomass in Indonesia, which is an agricultural country, has a high potential to be used as a substrate to produce biogas. One such biomass is cow dung and buffalo. In 2016, the production of cow and buffalo manure in Indonesia reached 345.7 thousand tons/day, which came from around 17.285 million animals (Directorate General of Livestock and Animal Health, Ministry of Agriculture, 2016). If all this waste is processed, then the energy potential that can be obtained is equivalent to the energy of replacing as much as 14.8 million liters of kerosene. As many as $98 \%$ of the total cattle and buffalo breeders are smallholder farmers spread across various villages in Indonesia, and the number of villages in Indonesia include almost $90 \%$ of the total village level administrative area (Central Statistics Agency, 2018). Most of the rural communities in Indonesia have the same characteristics, such as a low level of welfare and the lack of concern for the environment. This situation can be understood because the village community generally has a low level of education, with limited communication and transportation access. Therefore, community farmers need to be approached and assisted in ways that are appropriate to the character of rural communities in Indonesia to realize the diversification of renewable energy in the form of biogas from cow and buffalo manure (Central Statistics Agency, 2018).

Biogas technology dissemination programs for communities have been carried out in several countries with their respective challenges (Figueroa et al., 2017; Clemens et al., 2018; Wangs \& Banks, 2003; United Nations Development Programme, 2012). The 
biogas technology dissemination program for rural areas in Nepal is called the Biogas Support Program (BSP), which works with institutions such as the government, the private sector, and NGOs. These three players are effective for the realization of a checks-and-balances system, which is a prerequisite for the success for large scale programs. BSP has even played a role in shaping national policies and institutional frameworks regarding the promotion of renewable energy in rural Nepal. The program is also claimed to be a good example of programs across the country that have a propoor and inclusive orientation, operating through market mechanisms (United Nations Development Programme, 2012).

The International Renewable Energy Agency, which has a biogas technology dissemination program in Asia and Africa, highlighted the involvement of local leaders to raise awareness of the benefits of biogas for cooking, as well as the necessary behavioral changes. This program ensures a higher level of implementation. In addition, the acceptance of program implementation can be facilitated through pilot projects that provide concrete evidence. Overall, a strong and ongoing combination of incentive policies, adequate training for maintenance, construction, and financial evaluation is able to deal with obstacles in the field. All these factors are important in the implementation of household biogas in developing countries (Figueroa et al., 2017). Clemens et al. (2018) reported a biogas technology dissemination program in East Africa. Prior to 2007, the spread of biodigesters in Africa was very limited. The Africa Biogas Partnership Program began in 2009 and developed the biodigester market in East Africa even though the economy and finance in Sub-Saharan Africa were less profitable than those of countries in Asia.

The demand for biodigesters is increasing and new companies are moving markets, specifically in Kenya. Despite high upfront costs and limited access to credit, more than 27,000 biogas licensed households exist because biogas use provides major benefits to communities, which previously used firewood for cooking. People save money because they no longer buy firewood for cooking and can cook more cleanly and comfortably by using biodigesters. A fuel consumption test shows that households with biodigesters use 2.1 to 3.3 tons less wood per year than households without biodigesters. Gas is less available in East Africa, which is why cooking fuel requires firewood, making biogas 
more easily accepted. These experiences can be used as a lesson in the dissemination of biogas technology in Indonesia.

The Biogas-based Energy Security Village Program aims to provide awareness and knowledge to village communities about the potential for cow dung to be used as biogas and awareness of good environmental quality. The community is invited to build and operate a biogas digester, as well as utilize the produced biogas for cooking and lighting. With direct involvement, the community is expected to develop the skills needed to process cow manure into biogas. With their awareness and skills, the community is then expected to be able to maintain the sustainability of this program and even become agents of change for other villages. At the end of the program, all the planned digesters will be built to process $100 \%$ cow manure, thus ensuring that biogas can meet the energy needed by the entire village community for cooking and lighting even without electricity. The novelty of this program, which distinguishes it from other programs, is the evaluation of program sustainability going forward,based on simple economic calculations according to the conditions of the local community. Furthermore, companion programs are carried out to make rural biogas programs more attractive.

This program is conducted in Kediri Village, Gadingrejo Sub-District, Pringsewu District, Lampung, which is expected to be a pilot village in the future. This village is located about $30 \mathrm{~km}$ from Lampung University. Lampung University is located in Bandar Lampung, the capital of Lampung Province. Apart from being far from the city center, this village is also $4 \mathrm{~km}$ away from regency highways.

Most people work as conventional farmers within a small land area. They cultivate rain-fed rice fields, which have a lower harvest frequency than that of irrigated rice. Income from this work is low, being unable to meet daily needs such as food, clothing, shelter, energy costs, health, and school fees.

Seeing these conditions, the Pringsewu local government felt obliged to help the community improve their welfare. In 2012, the Animal Husbandry Department, with the district projection as a provider of breeding cows, provided revolving assistance of 30 heads of cattle for the community. This assistance was conducted intensively to ensure the birth of quality seed cows. Other residents who were not registered as members of farmer groups did not receive cows, yet they were also interested in participating in the cattle breeding program. With the capital of private cows, 30 residents participated in 
the fostered cattle program. Currently, a total of 60 heads of cattle are projected to give birth to breeding cows. In addition to the target cattle, other residents' cows are available; thus, about $90 \%$ of the villagers have cows.

However, the management of cow dung has not been well thought out. Cow dung is only thrown around cages and is used in the fields as fertilizer only at certain times and without prior processing. As a result, the environment becomes dirty, unhealthy, and smelly. Moreover, cow dung accumulates considerably around the integrated cage where 15 cows are kept simultaneously. Biogas that is released from the pile of cow dung is detrimental because the methane it contains will cause global warming.

Community empowerment is needed based on the condition of the people of Kediri. This approach is expected to improve welfare both in terms of economy and environmental quality. Empowerment is conducted for five years with the following stages: socialization, construction of a pilot digester, creation of a master design of the digester layout, construction of digesters according to the master design, and evaluation of the implementation of the program and its sustainability going forward.

\section{Methods}

The methods used in the Biogas-based Energy Security Program, which is carried out in stages for five years, are as follows:

1. Firstyear

(a) Socialization

The community is socialized as to the potential of cow dung being made into biogas, the importance of energy independence, and the importance of good environmental quality. This method is expected to provide people with knowledge of the potential of cow dung being used as energy, awareness of the importance of energy independence, and a quality environment. Socialization of is a key activity for communicating and dialoguing with the public. Socialization of community empowerment in the community helps improve the understanding of the community and related parties about the program. The socialization process builds community interest in playing a role and being involved in the program (Hadiyanti, 2008). Before and after socialization, a questionnaire was filled out to determine the success of the activity. This questionnaire is a 
quantitative approach that uses quantitative methods, with the aim of obtaining primary information from the community about community knowledge about biogas and its raw materials, community understanding of biogas safety, community knowledge and skills in building biogas installations, and community knowledge of good environmental quality. Around 50 people who were members of farmer groups and farmer women's groups filled out the questionnaire.

(b) Creating a master design of biogas digester layout for all villages

This method aims to maximize the digester that will be built later on the basis of the amount of cow dung. A master digester layout design was created for the whole village to ensure a systematic digester development program in the future (Syukri et al., 2014). Anyone who will carry out digester construction can refer to the existing master design. The position of the digester is adjusted to the position of the cage and house that will use biogas to ensure an optimal piping system. Generally, each digester will be used to supply biogas to three households. The master design of the digester layout is a reference for the construction of the digester and its installation so that it will be easy for anyone to continue development in the future.

(c) Construction of a biogas digester as pilot unit and installation of stoves and biogas lamps

The construction of this digester aims to provide a pilot unit for processing cow dung into biogas so that people can see their existence and feel the benefits. This method is expected to be effective in introducing and promoting the idea that biogas is indeed profitable.

\section{Second to fifth year}

The construction of the digester according to the design is carried out by the community together with a certified trainer, thus becoming a training venue for the community. In the construction of this digester, the community is involved in cost contributions, although not in the form of money. This approach provides people with a sense of ownership of the digester so that they will maintain it and 
ensure that it functions properly. The contributions of the residents come in the form of labor involved in digging digester holes and consumption, and accommodation for certified trainers who assist during digester construction and installation. The construction work also involves students of Real Work Lectures (KKN) from Universitas Lampung. All the digesters in the master layout design are expected to have been built by the end of the fifth year.

3. End of the fifth year

(a) Evaluation of the success of the program

Evaluation was conducted to find out the program's effect on environmental quality improvement as indicated by the percentage of manure treated and the level of energy independence in terms of the percentage of biogas use for cooking and lighting. This method is a quantitative approach, where the improvement of environmental quality is seen from how much cow manure is used to produce biogas so it does not pollute the environment. In terms of energy, the quantitative approach is carried out by reviewing how many households have successfully substituted their LPG needs with biogas for cooking and lighting when the electricity goes out.

(b) Evaluation of the program sustainability

Evaluation was carried out to determine the sustainability potential of processing cow manure into biogas in the future by the community after the end of the program. The cost of building a relatively expensive biogas digester will be an obstacle for rural communities, who generally face economic limitations.

\section{Result and Discussion}

3.1. Socialization of the potential of cow dung to be used as biogas, regarding environmental quality, and energy security

Socialization was conducted among farmer groups of 30 people and then among women farmer groups of 20 people. Before the socialization, a questionnaire was filled out to determine the condition of the respondents before the socialization. After the socialization, the questionnaire was filled out to see the condition of the respondents. 
This questionnaire is a quantitative approach with quantitative methods, with the aim of obtaining primary information from the community about community knowledge about biogas and its raw materials, community understanding of biogas safety, community knowledge and skills in building biogas installations, and community knowledge of good environmental quality. From the socialization, the following can be concluded:

Table 1. Data on questionnaire results before and after socialization

\begin{tabular}{|c|c|c|c|}
\hline No & Item & $\begin{array}{c}\text { Before } \\
\text { Socialization }\end{array}$ & $\begin{array}{c}\text { After } \\
\text { Socialization }\end{array}$ \\
\hline 1 & Know or not know about biogas & $10 \%$ know & $100 \%$ know \\
\hline 2 & $\begin{array}{l}\text { Whether the community knows } \\
\text { that cow manure can be made } \\
\text { into biogas }\end{array}$ & $10 \%$ know & $100 \%$ know \\
\hline 3 & $\begin{array}{l}\text { Community awareness in using } \\
\text { renewable energy and about } \\
\text { environment friendliness }\end{array}$ & $1 \%$ aware & $100 \%$ aware \\
\hline 4 & $\begin{array}{l}\text { Public knowledge about } \\
\text { environmental quality }\end{array}$ & $2 \%$ know & $100 \%$ know \\
\hline 5 & $\begin{array}{l}\text { Desire of the community to } \\
\text { process cow manure into biogas }\end{array}$ & $1 \%$ want & $80 \%$ want \\
\hline 6 & $\begin{array}{l}\text { Level of community approval if a } \\
\text { biogas digester unit is built }\end{array}$ & $1 \%$ agree & $100 \%$ agree \\
\hline
\end{tabular}

Source: Authors (2014)

The questionnaire results show that the socialization successfully provided initial information about transforming cow dung into biogas and made people aware of the importance of renewable energy and good environmental quality. The socialization also successfully persuaded the public to trying using biogas technology. Prior to the socialization was carried out, the community knew very little about biogas, and few knew that cow dung could be processed into biogas. After the socialization, the increase in the respondents' knowledge was only around 90\%. This result is different from the knowledge and care about good environmental quality, the desire and concern to use alternative energy, and the desire to process cow dung into biogas with the construction of a digester. These last items increased in value to close to $100 \%$ after the socialization, 
bearing in mind that in the beginning, the community still lacked knowledge and concern about these matters.

\subsection{Construction and operation of digester, biogas stoves, and biogas lamps}

In the first year, two biogas digester units with a capacity of 10 and $4 \mathrm{~m}^{3}$ were designated as pilot units, with four biogas stove installations and four biogas lamp installations used by four households. The construction of the two digesters was funded by the Ministry of Research, Technology, and Higher education, Republic of Indonesia. With these units, the community was expected to learn directly about biogas and feel its benefits. This pilot development was effective in introducing biogas technology and in making people accept this technology easily because the community saw firsthand that the use of biogas is safe and that residents with biogas-fed homes no longer buy LPG for cooking and still have lighting when the electricity goes out. Thus, the community was enthusiastic and eager to use biogas. This development was conducted by the community together with certified trainers. The community helped dig a large digester hole. Their participation provided the community with a greater sense of ownership of the digester. The most common obstacle encountered during the construction of the digester was the excavation, which took a long time because of large stones that hindered the excavation and needed to be broken down to be moved. Moreover, rainy weather slowed down the construction's drying process. 
Sri Ismiyati Damayanti, Simparmin Ginting, Otik Nawansih, Siti Hudaidah | ASEAN Journal of Community Engagement | Volume 4, Number 1, 2020

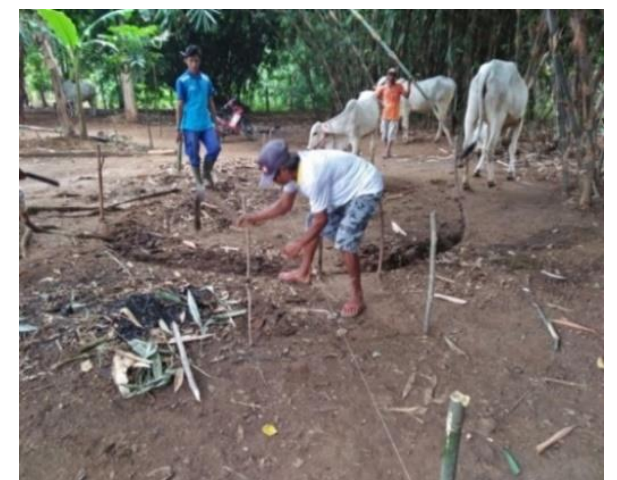

(a)

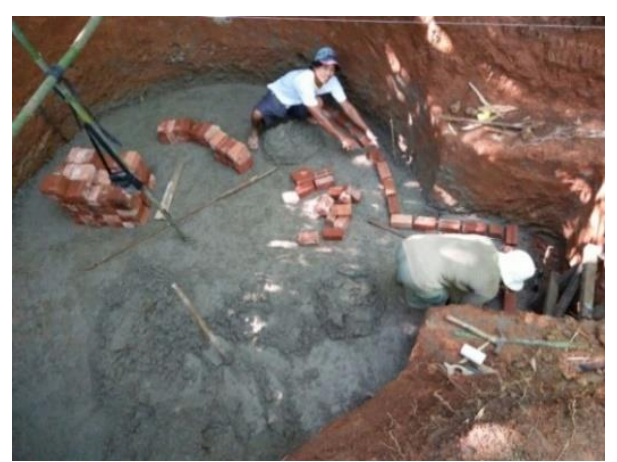

(c)

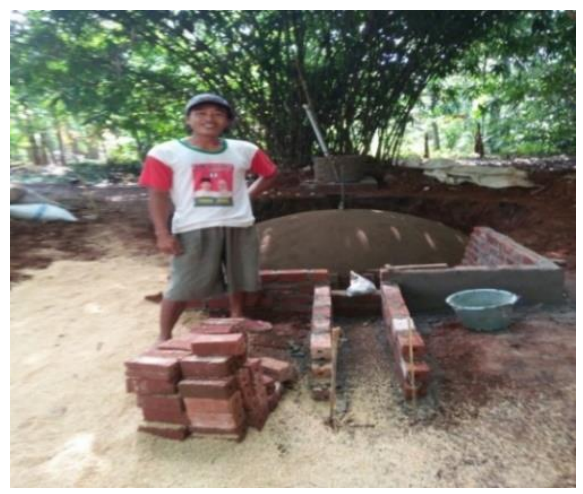

(e)

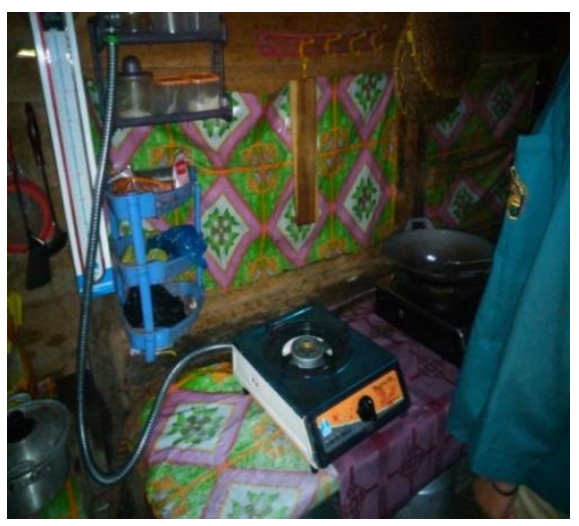

$(\mathrm{g})$

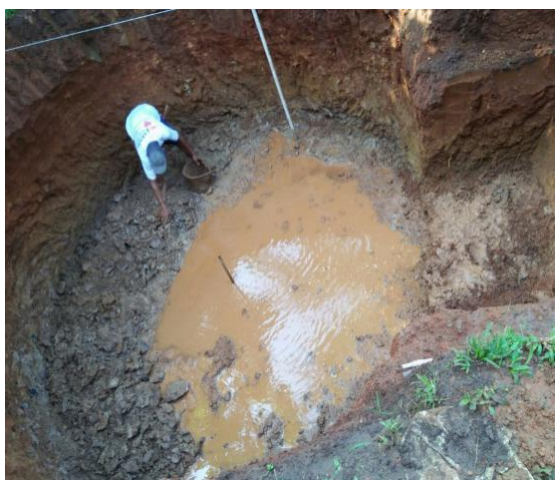

(b)

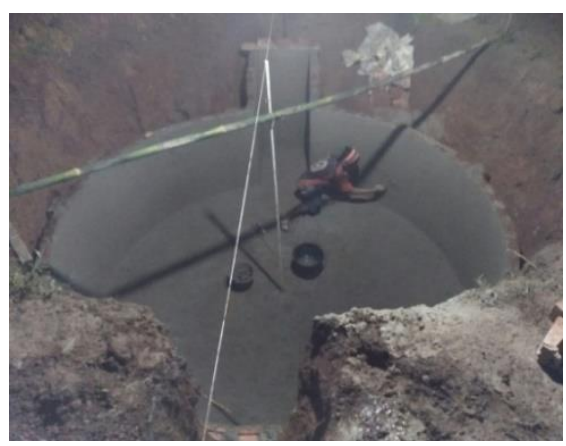

(d)

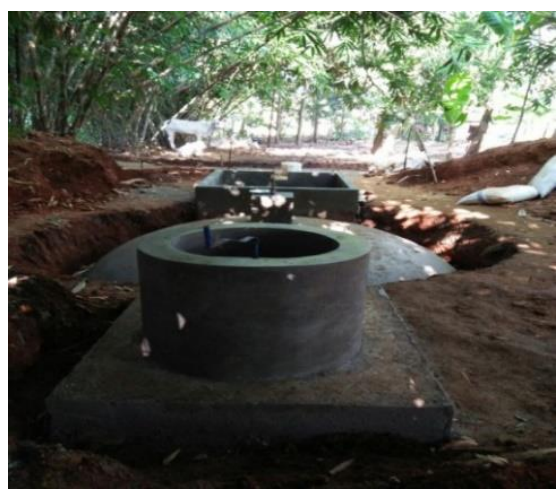

(f)

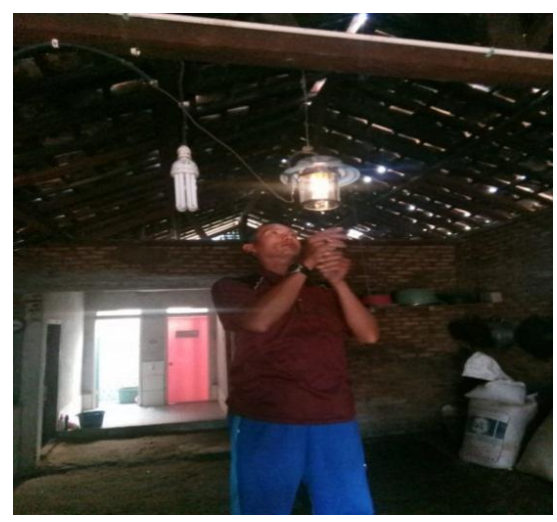

(h)

Fg. 2 (a); (b); (c); (d); (e); (f); (g); and (h) Construction of a biogas digester and installation of biogas stoves and biogas lamps 


\subsection{Master design of the digester layout throughout the village}

Once the community became interested in implementing biogas technology from cow dung, a master layout design of the digester was created for the entire village for future use. This design plan contains the layout of the digester, which is based on the distance of the house to be fed with biogas and the distance of the cage points where cow manure is produced to ensure an optimal piping system and processing of cow manure into biogas. Generally, each digester will be used to supply biogas to three households. The master design of the digester layout serves as a reference for the construction of the digester and its installation so that it will be easy for anyone to continue development in the future. Based on the master design, a total of 20 digesters are needed for the whole village. Figure 4 shows the master design for the digester layout.

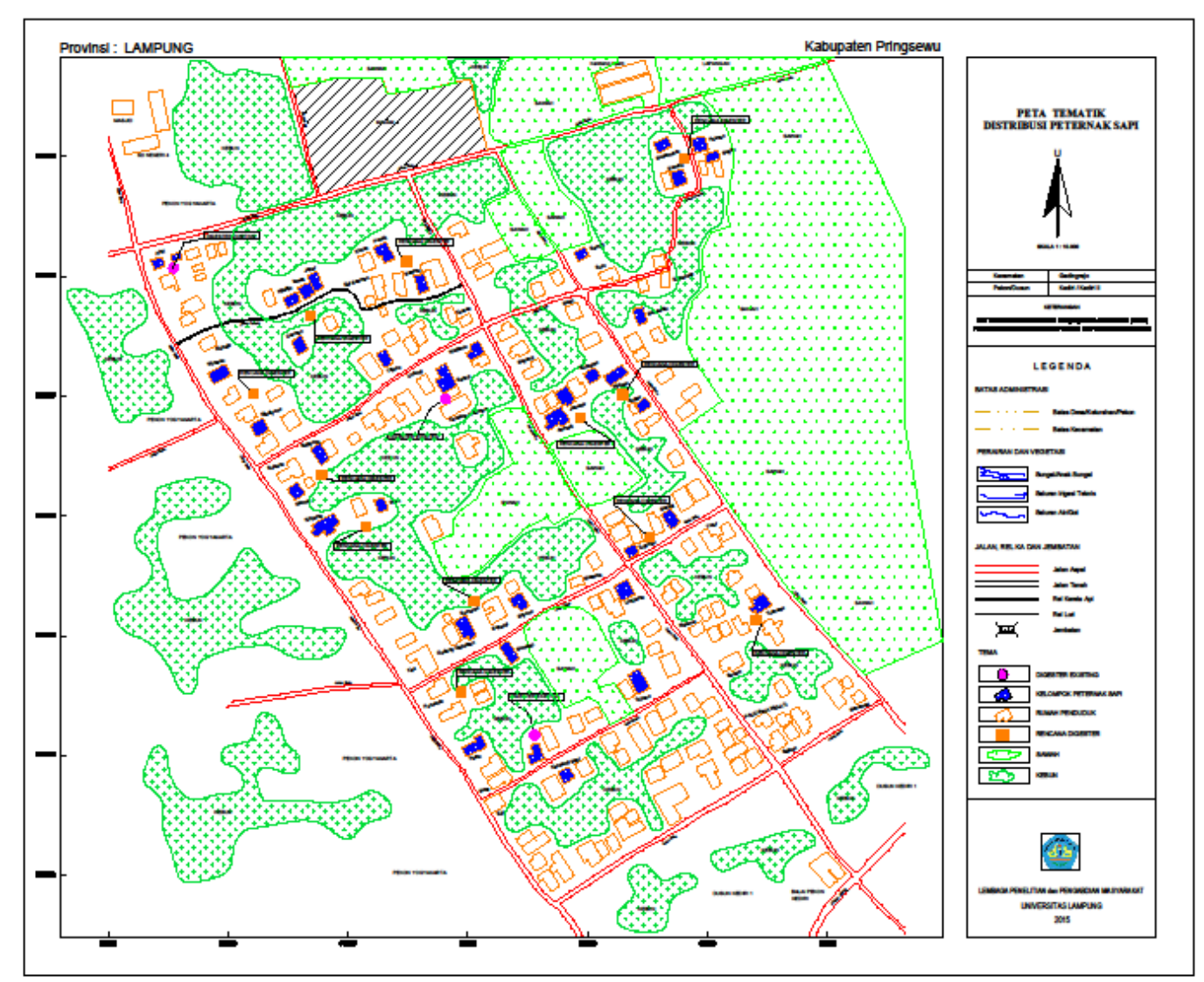

Fg. 3 Master design of the digester layout throughout the village Source: Authors (2014) 


\subsection{Construction of a biogas digester according to the master design}

The construction of the biogas digester and the installation of stoves and biogas lamps were conducted during the second to the fifth year. Five biogas digesters, which were used by around 12 households, were built over this time period. The construction of these digesters was funded by the Republic of Indonesia's Ministry of Research, Technology, and Higher Education through various community service grant schemes. Development is still carried out by the community accompanied by certified personnel to train the community in building digesters. The addition of digesters is slow due to lack of funding support; funding comes only from the Ministry of Higher Education. A more intensive approach was adopted with the regional government of Pringsewu to solve this problem. A relationship was established with the regional head and his staff related to energy, the environment, and food security to show them the biogas technology. A pilot digester unit and the installation of a built-in biogas stove were presented. This partnership has had a positive impact on revenue; the following fiscal year, the local government funded the construction of a biogas digester in the village of Kediri. The biogas program was supported by local government funds for two years, with a total of four digesters being built. At the end of the fifth year, the construction of five biogas digesters was funded by political parties that won votes in the Kediri area. By the fifth year, 20 digesters were built in the village of Kediri, which could supply biogas to around 30 households.

During the four years of development, several digesters had construction sites that did not match the existing master design of the digester layout because of the movement of livestock in the community. In smallholder farmers with limited capital, cattle mobilization is possible.

Based on the number of digesters that should have been built, $60 \%$ of the development target has been reached, with a 30\% target use. The low use of biogas is due to the distance between several houses that are relatively far from the digester, thereby preventing the easy flow of biogas using pipes. A possible solution is to add pressure to biogas so that it can reach farther places. This program also involves KKN students from Lampung University, thereby allowing these students to understand the reality of a portion of Indonesian society and foster empathy and willingness to provide 
solutions to community problems. The expectation is that future scholars will be both intelligent and socially aware, which is necessary to the development of Indonesia.

\subsection{Evaluation of program success}

The program was evaluated at the end of the fifth year. Results showed that the program succeeded in achieving its objectives; the community was enthusiastic about using biogas technology from cow dung. Over five years of operation, the construction went smoothly, the entire digester was still operating well, and biogas was still being used for cooking and lighting when the electricity went out. Biogas supplies $100 \%$ of the energy needs of biogas-fed houses for cooking and lighting when the electricity goes out. Thirty percent of the community has been able to access biogas. A large amount of biogas is produced and can be used by more people. However, access has been hampered because biogas could not flow to houses that are far from the digester. The environment quality has also improved, as indicated by the cleanliness of cages and home environments. As much as $60 \%$ of available cow dung has been processed into biogas by the 11 digesters constructed so far (Fajriyanto \& Damayanti, 2014; Ginting \& Damayanti, 2015; Damayanti \& Nawansih, 2016; Ginting et al., 2018). In this program, the addition of digester units was slow because the community could not build a more expensive digester. Biogas combustion is cleaner than other forms of combustion, thus improving the environment quality, reducing fossil energy use, and decreasing the greenhouse effect.

\subsection{Sustainability evaluation of cow manure management into biogas}

Although the program has succeeded, the sustainability of processing cow manure into biogas after the program ends needs to be evaluated. This evaluation is based on simple economic calculations in accordance with the conditions of the local community, and a companion program that optimizes the presence of the biogas digester needs to be established so that the rural biogas program becomes economically attractive.

For rural communities who generally have economic limitations, the cost of building a relatively expensive biogas digester will be an obstacle. If environmental factors are not used as parameters of the benefits received, then the high costs of building a 
digester that produces only biogas is certainly not economically attractive. The following simple economic evaluation gives an illustration of this situation.

Table 2. Details of the costs of using biogas compared with LPG

Expenditures for the construction of digester and installation of biogas lamps and biogas stoves

1. Construction of one digester : $\$ 1,010.04 \quad$ Rp. 15.000.000,with a capacity of $12 \mathrm{~m}^{3}$, which can supply biogas for four households

2. Cost of installing biogas stoves $\$ 404.02 \quad$ Rp. 6.000.000,and biogas lamps for four households @ Rp.1,500,000

Total cost of building a digester $\$ 1,414.06$ Rp. 21.000.000,and four sets of biogas lamps and biogas stoves installations for four households

Total cost to be borne by one \$353.51 Rp. $5.250 .000,-$ household Assumption: the validity period of the 10-year digester (Yayasan Rumah Energi, 2019) Costs to be incurred by one : $\$ 2.95 \quad$ Rp. 43.750,household (if calculated every month)

\begin{tabular}{|c|c|c|c|}
\hline \multicolumn{4}{|c|}{ Expenditures for purchasing 3 kg LPG gas } \\
\hline Price of $3 \mathrm{~kg}$ LPG & $:$ & $\$ 1.68$ & Rp. 25.000,- \\
\hline $\begin{array}{l}\text { Cost of purchasing LPG gas in } 1 \\
\text { month/household (assuming a } \\
\text { purchase of two tubes) (Aria, 2020) }\end{array}$ & $:$ & $\$ 3.37$ & Rp. 50.000,- \\
\hline Kurs : $1 \$=\operatorname{Rp}$ & גטן & nesia, 2 & \\
\hline
\end{tabular}
Source: Authors (2019)

The above economic evaluation above shows that the monthly costs that must be incurred by the community to obtain biogas do not differ greatly from the costs of 
obtaining LPG. However, the cost of obtaining biogas cannot be paid in monthly installments but must be available in large quantities at the beginning of the construction of the digester. This option is economically unattractive for rural communities with limited economic conditions. This situation is different from what happened in East Africa (Clemens et al., 2018), in which almost no gas is available for cooking, which is why only wood has been used as cooking fuel, thereby making the implementation of biogas easier. Although the people in East Africa covered by the study have lower financial capability than people in Asia, the benefits of replacing firewood with biogas motivated them to change, especially with financial assistance in the form of financial credit. In the future, a scheme needs to be developed to fund the construction of affordable biogas digesters or the optimization of the use of biogas digesters, where biogas that is abundant, if only used to meet daily cooking needs, can be used to support small food businesses. The bio slurry output of biogas digesters, which are quality organic fertilizers, can be further assessed for their use and commercial value to increase the economic value of the biogas digesters.

At present, the people of Kediri Village have turned their yards into sustainable food home areas that aim to meet the needs of their families for healthful vegetables and fruits. These vegetables and fruits can be obtained because the fertilizer used is bioslurry organic fertilizer, which is the output of the digester. If the harvest from the yard is more than what a family needs, then the rest is sold. Proceeds from sales can marginally supplement a family's income, providing an average additional income of around IDR 300,000/month. The minimal use of bioslurry can generate a small amount of additional income. If bioslurry is processed commercially on a large scale, then this option becomes economically attractive.

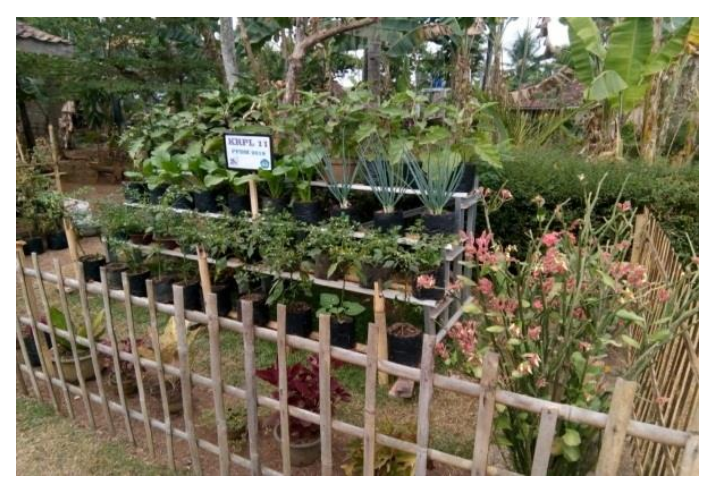

Fg. 4 Sustainable food home area Source: Authors (2019) 
The biogas digester provides many benefits to the community, such as the availability of quality vegetables for families and additional income from the sale of these vegetables. Utilization of abundantly available biogas has also been thought of. The plan is for biogas to be used as fuel for small food businesses that will be managed by a group of farm women. Various forms of assistance have been extended, including training in making twigs and refining used cooking oil for frying twigs. Knowledge about the use of refined cooking oil is important so that the resulting twigs remain in accordance with health standards by using cooking oil efficiently. The local government of Pringsewu also contributed by providing cooking equipment. In the future, if this small industry runs and becomes a promising business, then it will make this biogas program even more attractive economically.

\section{Conclusion}

The Biogas-based Energy Security Program successfully promoted the community's awareness, acceptance, and application of the technology of processing cow manure into biogas. In biogas-fed houses, biogas supplied 100\% of energy needs for cooking and lighting when the electricity goes out. About $30 \%$ of the community has been able to access biogas. With as much as $60 \%$ of cow manure being processed into biogas, the quality of the environment has improved, as shown by the cleanliness of cages and the home environment. The use of fossil energy and GHG pollution effects are also reduced. The sustainability of processing cow manure into biogas is a challenge, given the cost of building biogas digesters, which are relatively expensive for rural communities. If environmental factors are not used as parameters of the obtained benefits, then the management of cow manure into biogas becomes economically unattractive. Funding schemes for the construction of affordable biogas digesters are needed, and the utilization of biogas digesters, especially the utilization of bioslurry, needs to be optimized.

\section{Author Contribution}

All authors were involved, together with the community, when implementing the program. Simparmin Br Ginting supervised the construction of the digester along with the installation of biogas lamp-stoves, ranging from the purchase of building materials 
to the digester can function properly. Otik Nawansih and Siti Hudaidah are responsible for providing program socialization and program-related questionnaires to the public. Sri Ismiyati Damayanti prepared a grand design layout of the digester, supervised all activities, and established good relations with village elements. All authors discussed the results and contributed to the final manuscript.

\section{Acknowledgements}

Author would like to thank to the Directorate of Research and Community Service, Ministry of Research, Technology, and Higher Education (DRPM, Kemenristekdikti) for the Community Service Grant “Iptek bagi Masyarakat (IbM)” 2014 and 2015 fiscal years, "KKN- PPM "2016 fiscal year, and "Program Pengembangan Desa Mitra (PPDM)" 2018 fiscal year, which is the financial supporter of this program.

\section{References}

Aria, P. (2020, Januari 23). The pros and cons of increasing the price of LPG $3 \mathrm{~kg}$. https://katadata.co.id/telaah/2020/01/23/pro-kontra-rencana-kenaikan-hargaelpiji-3-kilogram

Bank Indonesia. (2020, July 20). Informasi Kurs. https://www.bi.go.id/id/moneter/informasi-kurs/transaksi-bi/Default.aspx

Bibra, M., Wang, J., Squillace, P., Pinkelman, R., Papendick, S., Schneiderman, S., ... Sani, R. K. (2015). Biofuels and Value-added Products from Extremophiles. In Advances in Biotechnology (pp. 17-51). New Delhi: I.K. International Publishing House. https://www.researchgate.net/publication/282574277_Biofuels_and_Valueadded_Products_from_Extremophiles

Brioukhanov, A. L., \& Netrusov, A. I. (2007). Aerotolerance of Strictly Anaerobic Microorganisms and Factors of Defense against Oxidative Stress : A Review. Applied Biochemistry and Microbiology, 43(6), 567-568. 
Capellan-Perez, I., Mediavilla, M., Castro, C., De, Carpintero, O., \& Miguel, L. J. (2014). Fossil fuel depletion and socio-economic scenarios : an integrated approach. Energy. https://doi.org/10.1016/j.energy.2014.09.063

Central Statistics Agency, R. of I. (2018). Official Gazette of Statistics: Results of Village Potential Data Collection 2018. Jakarta.

https://www.bps.go.id/pressrelease/2018/12/10/1536/hasil-pendataan-potensidesa--podes--2018.html

Chojnacka, A., Szczesny, P., Blaszczyk, M. K., Zielenkiewicz, U., Detman, A., Salamon, A., \& Sikora, A. (2015). Noteworthy Facts about a Methane- Producing Microbial Community Processing Acidic Effluent from Sugar Beet Molasses Fermentation. Plos One, 1-23.

https://doi.org/10.1371/journal.pone.0128008

Clemens, H., Bailis, R., Nyambane, A., \& Ndung, V. (2018). Energy for Sustainable Development Africa Biogas Partnership Program: A review of clean cooking implementation through market development in East Africa. Energy for Sustainable Development, 46, 23-31.

https://doi.org/10.1016/j.esd.2018.05.012

Damayanti, S. I., \& Nawansih, O. (2016). Final report on KKN-PPM grants: Empowerment of Cattle Farmers and Farmer Women's Groups Towards the Establishment of an Independent Energy and Organic Food Village. Bandar Lampung.

Deublein, D., \& Steinhauser, A. (2008). Biogas from Waste and Renewable Resources. (D. Deublein \& A. Steinhauser, Eds.). Weinheim: WILEY-VCH.

Directorate General of Livestock and Animal Health, Ministry of Agriculture, R. of I. (2016). Livestock and Animal Health Statistics 2016. Jakarta: Directorate General of Livestock and Animal Health, Ministry of Agriculture, Republic of Indonesia.

http://pusvetma.ditjenpkh.pertanian.go.id/upload/statistik/1533987093.Buku\%20 Statistik\%202016\%20Final.pdf

Fajriyanto, \& Damayanti, S. I. (2014). Final Report on Science and Technology for the Community (IbM) Cattle Breed Groups in Kediri Village, Gadingrejo, Pringsewu, Lampung. Bandar Lampung. 
Figueroa, A., Boshell, F., Velzen, L. van, \& Anisie, A. (2017). Biogas for Domestic Cooking. Abu Dhabi: International Renewable Energy Agency. Retrieved from https://www.irena.org/

Ginting, S. B., \& Damayanti, S. I. (2015). Final Report of Science and Technology for the Community (IbM) Cattle Farmer Group: Management of Cattle Manure in Integrated Stables to Produce Biogas as Fuel for Enclosure Lighting. Bandar Lampung: Lembaga Penelitian dan Pengabdian Masyarakat (Unpublished).

Ginting, S. B., Nawansih, O., \& Hudaidah, S. (2018). 1st Year Report on Partner Village Development Program: Towards a Community-Based Productive Village with Optimization of Rural Resource Utilization. Bandar Lampung: Lembaga Penelitian dan Pengabdian Masyarakat (Unpublished).

Hadiyanti, P. (2008). Strategi Pemberdayaan Masyarakat melalui Program Keterampilan Produktif di PKBM Rawasari, Jakarta Timur. Perspektif Ilmu Pendidikan, 17(April), 90-99.

https://doi.org/10.21009/PIP.171.10

Kalyani, V. L., Dudy, M. K., \& Pareek, S. (2015). GREEN ENERGY: The NEED of the. Journal of M anagement Engineering and Information Technology, 2(5). https://www.researchgate.net/profile/Vijay_Kalyani/publication/283482870_GREE N_ENERGY_The_NEED_of_the_WORLD/links/5639d6e408aecf1d92aac95d.pdf

Khairuddin, N., Manaf, L. A., Hassan, M. A., Halimoon, N., Azlina, W., \& Ab, W. (2015). Biogas Harvesting from Organic Fraction of Municipal Solid Waste as a Renewable Energy Resource in Malaysia : A Review. Pol. J. Environ. Stud, 24(4), 1477-1490. https://doi.org/10.15244/pjoes/34670

Lim, J. W., Chiam, J. A., \& Wang, J.-Y. (2014). Microbial community structure reveals how microaeration improves fermentation during anaerobic co-digestion of brown water and food waste. Bioresource Technology, 171, 132-138.

https://doi.org/10.1016/j.biortech.2014.08.050

Lim, J. W., \& Wang, J.-Y. (2013). Enhanced hydrolysis and methane yield by applying microaeration pretreatment to the anaerobic co-digestion of brown water and food waste. Waste Management, 33(4), 813-819. 
Linke, B., Muha, I., Wittum, G., \& Plogsties, V. (2013). Mesophilic anaerobic co-digestion of cow manure and biogas crops in full scale German biogas plants: A model for calculating the effect of hydraulic retention time and VS crop proportion in the mixture on methane yield from digeste. Bioresource Technology, 130, 689-695.

\section{https://doi.org/10.1016/j.biortech.2012.11.137}

Meyer-aurich, A., Schattauer, A., Jürgen, H., Klauss, H., Plöchl, M., \& Berg, W. (2012). Impact of uncertainties on greenhouse gas mitigation potential of biogas production from agricultural resources. Renewable Energy, 37.

https://doi.org/10.1016/j.renene.2011.06.030

Nathia-Neves, G., Berni, M., Dragone, G., Mussatto, S. I., \& Forster-Carneiro, T. (2018). Anaerobic digestion process: technological aspects and recent developments. International Journal of Environmental Science and Technology, 15, 2033-2046. https://doi.org/10.1007/s13762-018-1682-2

Nguyen, D., \& Khanal, S. K. (2018). A little breath of fresh air into an anaerobic system : How microaeration facilitates anaerobic digestion process. Biotechnology Advances, 36(7), 1971-1983.

\section{https://doi.org/10.1016/j.biotechadv.2018.08.007}

Omer, A. (2017). Biogas technology for sustainable energy generation : development and perspectives. MOJ Applied Bionics and Biomechanics, 1(4), 137-148.

https://doi.org/10.15406/mojabb.2017.01.00022

Ošlaj, M., \& Muršec, B. (2010). Biogas as a renewable energy source. Technical Gazette, 109-114.

https://www.researchgate.net/publication/287624649_Biogas_as_a_renewable_ene rgy_source

Owusu, P. A., \& Asumadu-sarkodie, S. (2016). A review of renewable energy sources , sustainability issues and climate change mitigation. Cogent Engineering, 15(1). https://doi.org/10.1080/23311916.2016.1167990

Panwar, N. L., Kaushik, S. C., \& Kothari, S. (2011). Role of renewable energy sources in environmental protection: A review. Renewable and Sustainable Energy Reviews, 15, 1513-1524. 
Poh, P. E., \& Chong, M. F. (2009). Development of anaerobic digestion methods for palm oil mill effluent ( POME ) treatment. Bioresource Technology, 100, 1-9. https://doi.org/10.1016/j.biortech.2008.06.022

Seadi, T., Al, Rutz, D., Prassl, H., Kottner, M., Finsterwalder, T., Volk, S., \& Janssen, R. (2008). Biogas Handbook. (T. Al Saedi, Ed.). DK-6700 Esbjerg, Denmark: University of Southern Denmark Esbjerg, Niels Bohrs Vej 9-10, DK-6700 Esbjerg, Denmark. https://www.lemvigbiogas.com/BiogasHandbook.pdf

Sharma, A., Laudari, R., Rijal, K., \& Adhikari, L. (2019). Role of Biogas in Climate Change Mitigation and Adaptation. Journal of Forest and Natural Resource Management, 1(1), $25-31$.

\section{http://doi.org/10.3126/jfnrm.v1i1.22649}

Syukri, M., Hastuti, Akhmadi, Kartawijaya, \& Kurniawan, A. (2014). Studi Kualitatif Proliferasi dan Integrasi Program Pemberdayaan Masyarakat di Jawa Tengah , Nusa Tenggara Barat, dan Sulawesi Selatan. Jakarta: Lembaga Penelitian SMERU https://www.smeru.or.id/sites/default/files/publication/pnpmintegrasi.pdf

United Nations Development Programme. (2012). Making Energy Markets Work for The Poor: Large-Scale Dissemination of Biogas Plants in Nepal. (N. Beresnev \& C. Piprell, Eds.). Bangkok.

https://snv.org/cms/sites/default/files/explore/download/making_energy_markets _work_for_the_poor_nepal_2012.pdf

Uzodinma, E., Ofoefule, A. U., \& Oparaku, O. U. (2014). The Role of Biogas in Mitigating Climate Change. Nigerian Journal of Solar Energy, 25, 85-90.

https://www.researchgate.net/publication/324174063_The_role_of_biogas_in_mitig ating_climate_change/link/5ac496f6aca27218eabc5bd3/download

Wangs, Z., \& Banks, C. J. (2003). Evaluation of a two stage anaerobic digester for the treatment of mixed abattoir wastes. Process Biochemistry, 38(9), 1267-1273.

https://doi.org/10.1016/S0032-9592(02)00324-2

Weiland, P. (2010). Biogas production : current state and perspectives. Appl Microbiol Biotechnol, 85, 849-860. 
Yin, J., Yu, X., Zhang, Y., Shen, D., Wang, M., Long, Y., \& Chen, T. (2016). Enhancement of acidogenic fermentation for volatile fatty acid production from food waste : Effect of redox potential and inoculum. Bioresource Technology, 216, 996-1003.

https://doi.org/10.1016/j.biortech.2016.06.053 